Stellenbosch Theological Journal 2021, Vol 7, No 1, 1-14

DOI: http://dx.doi.org/10.17570/stj.2021.v7n1.a15

Online ISSN 2226-2385 | Print ISSN 0028-2006

2021 () Pieter de Waal Neethling Trust

\title{
Access to land in sub-Saharan Africa: the church as an unnoticed accomplice
}

\author{
Kasebwe Timothee Luc Kabongo \\ University of Pretoria \\ Pretoria, South Africa \\ luc.kabongo@novo.org \\ ORCID ID: https://orcid.org/0000-0001-8343-1794
}

\begin{abstract}
The access to land for Africans in sub-Saharan Africa has been problematic since the advent of colonisation. The church came to Africa as an acolyte of colonisers and acquired land as a benefit from its association. The minority of people still own the majority of land through title deeds, a Eurocentric view of land based on private ownership, while the landless (the majority of Africans) are still hoping their respective governments would redistribute equitably the land so that they could have access to their birth right inheritance from their Creator and their ancestors (Afrocentric view). The church is part of the minority that owns vast pieces of land. Different subSaharan African governments have proven to be incapable to do fair and equitable land redistributions. This article asks the question about how the church could be a role player in the democratisation of access to land. It stresses that the church could be a proactive role player in this issue of access to land by making its current land assets accessible to local communities as well as advocating for speedy land redistribution by governments. This article ends by highlighting proactive action of land access by some local churches to illustrate what the church can do and inspire others to follow suit.
\end{abstract}

Keywords

Access, Afrocentric, democratisation, Eurocentric, privilege, shalom.

\section{Introduction}

The colonial history of Africa created a problem of access to land that indigenous Africans are still at pains with. Currently, "across much of Africa, land ownership and distribution remain volatile issues" (Maathai 2009:227). Colonisation led "to land ownership being historically determined by race" and political power (Holtzhausen 2015:1). In various 
African countries, colonizers "displaced large numbers of native Africans to make way for European settlers" (Maathai 2009:227). On arrival, the colonisers introduced a new concept of access to land which had to be owned and proof of ownership had to be issued in the form of a title deed.

Access to land is a major issue in many sub-Saharan African countries. Many scholars have reflected on it and have given their opinions of the matter (Bolnick and van Rensburg 2005; Resane, 2019; Maathai, 2009; Muzenda 2020:4). They point out to the need for equity and justice that many Africans do not experience yet. They stress that our "shared humanity and interconnectedness" make the reality of the lack of access to land for many Africans, a justice issue worth advocating for (Holtzhausen 2015:4). Advocacy efforts are motivated by the desire to see a collective improvement of the quality of life of all Africans, especially the poor. For example, currently, $62 \%$ of the African urban population lives in slums and various kinds of informal settlements where their living conditions are not good (De Beer 2020b:1). And the lack of access to land is one of the major problems which worsens their living conditions.

The current challenges of access to land can also be blamed on the church. Christianity has played the role of an oppressor who took advantage of the existing land of indigenous Africans to promote its agenda. Many denominations "were involved in the process which left" ordinary Africans landless (Nkosi 1999:1). Some "denominations still own the land that was given to them" by colonising governments and existing African governments (Resane 2019:2).

These historical facts place the church as a privileged role player in the current conversation on access to land in sub-Saharan Africa. The church is meant to be known by the way it loves and cares (Jn 13:35). Access to land is a meaningful issue for many Africans. One could even argue that "land has always been the source of life in Africa ... it produces what is needed for consumption", protection in the form of shelter and keeps the living and the dead united as one family (Muzenda 2020:4). The land has always been the epicentre of "wars and political and social disturbances" throughout the history of Africa whenever access to it is not equitable (Muzenda 2020:4). This article uses the biblical interpretive framework of Jeremiah 29:7 to reflect on how the church could use its privilege of land 
ownership to be a blessing to communities of the landless. It asks: how can the church participate in the democratisation of access to land?

\section{The biblical interpretation of Jeremiah 29:7}

Jeremiah 29 narrates the story of the Israelites being in exile as a punishment from God because of disobedience. The prophet Hananiah came soon after this forced removal to tell the Israelites that God will free them up and they will return to Israel after 2 years. This is a lie that Jeremiah came to refute. He challenged the Israelites to not be passive refugees waiting to go back home, but to be active residents in tangibly "participating" in the wellbeing of their host country because such efforts would benefit them in return (Ofo'ia, 2017). This passage points out the critical role believers could play in society by seeking the improvement of the quality of life of their context through an issue such as land access. Brueggemann (2001:8) sees this passage as "the clearest model for prophetic imagination and ministry" of the church participation in bringing equity and justice in society. Such participation could lead the church to contend in a small way for the majority of sub-Saharan Africans who have no access to land. The more land will be accessible to all, the more Africa will be a shalom community for all. A shalom community is "an environment where socioeconomic justice is available to all and community's problems and their resolve is a concern for all" (Linthicum 2003:38). In such a community "seeking the spiritual, social and environmental peace of [everyone] is more significant [to their] collective future" (Hayes 2006:15). In some ways, it could mean to "transfer access to and ownership of land from those who have a lot to those who have nothing" (Weiner \& Harris 2003:87). This would lead to the democratisation of access to land which is the African traditional understanding of the land. In traditional Africa, "land was perceived as a communal property and largely each tribal group enjoyed an exclusive ownership of the same land" (Muzenda 2020:4). This land was inherited intergenerationally. It was not only an asset for "sociocultural" meaning but also a "spiritual asset that was shared and controlled within communities" (Muzenda 2020:4). Tribal chiefs made sure that every member of the community "had some land to produce food" (Muzenda 2020:4). This was because there was a general belief that the land belongs to God who made it available for the use of the whole community. Therefore, 
no one "had the right to sell land as a commodity" (Amanze 2002:304). Some tribes "identify themselves by referring to the land on which they lived. An area occupied by a clan would be called by that clan's name" (Vorster 2019:6). Even "all the major wars of liberation in sub-Saharan Africa were to liberate the ... stolen land” (Hambira 1999:1-2).

It could be argued that the church isn't a major landowner in a country and therefore it should focus on challenging major landowners to redistribute it. While this is a valid argument, it should not discount the church as a privileged role player in this issue of land access. Some denominations have acknowledged the need for the church to be a role player. The Catholic bishops of Southern Africa, for example, stress that "the land belongs to God and is given into the care of all God's people..." without exclusion (Catholic Church 2012:2). The Methodist Church of Southern Africa committed to use the land it owns to participle in addressing "the needs of some of the most impoverished communities" (Bolnick and van Rensburg 2005:115). They stressed that government alone cannot address the acute shortage of land

The current conversation on access to land is seen from two different perspectives. The first one sees land as a "life story of sacrifice and hardship" (Niemandt 2019: 2). The other one sees it as a symbol of "suppression and emotions of deep loss and disenfranchisement" (Niemandt 2019: 2). The first perspective is seen in the value in title deeds, whereas the second is seen in the form of communal access to physical land. It is important to dissect these two perspectives and how the church seems to interact with them.

\section{The two perspectives}

Christianity came to Africa as a partner with the colonial enterprise and embraced a Eurocentric view (private ownership) ofland while preaching the message of altruistic love which resonated with the African value in mutual solidarity which translates into shared land access. This was a tangible contradiction that compromised its prophetic mandate of "compassion and forgiveness, of love for the poor and the weak" Terreblanche (2014:26). This historical baggage is still a reality in current Africa. Katongole (2017: 21) stresses that "Christian theology and practice have tended to readily 
and uncritically surrender" to established powers. This surrender is seen by how the church in sub-Saharan Africa seems to have maintained a Eurocentric view of the land that views land as an exclusive "commodity to be purchased and sold" (Tafira 2015:1). When the church accompanied the colonisers to explore and occupy Africa, it "stumbled across vast swathes of land, viewed them as a stroke of fortune. The land provided an opportunity for accumulation, wealth and prosperity" (Tafira 2015:1). In light of this fact, one may argue that Africa has been "a victim" of many institutions, including the church (Terreblanche 2014:342). Churches are still "owning tracts of land from which original inhabitants" were removed (Resane 2019:1).

The Afrocentric view on land which sees access to land as a birth right for all seems to be unpopular within the church and the African political elite who used land access as the pillar of their liberation struggle before the independence of their respective countries. Nowadays, land access has "changed hands" from colonisers to neo-colonisers (Maathai 2009:228). There is a general failure of post-colonial Africa to equitably redistribute land to the majority of Africans. In this regard, disputes, and contestation over the control of land have occurred between and within states. Access to land has become the focus of a constant struggle between the forces of dispossession, greed, exploitation and land-grabbing ..." (Resane 2019:1). The African liberation struggle motivations to liberate the land and make it available to the majority of Africans have been captured by forces of greed. Few so-called liberation heroes are the symbol of that contradiction. This article will illustrate the legacy of the Popular Movement of Liberation in former Zaire (now the Democratic Republic of Congo), the ZANU PF in Zimbabwe and the ANC in South Africa.

\subsection{Zaire and Mobutu's ideology of return to authenticity}

The former president of Zaire described his ideology of authenticity as a way to "discover our personality by reaching into the depths of our past for the rich cultural heritage left to us by our ancestors" (Meredith 2011:207). As a way of implementing this ideology," the Zairian ruling party led by Mobutu expropriated land from foreign nationals" (Kabuya 1995:54). From 1973, Mobutu called for an expropriation of land, small and mid-sized businesses belonging to foreigners. The beneficiaries were the party elite 
who knew very little to nothing about agriculture or business. The result of the implementation of this philosophy of authenticity was disastrous and plunged the country into an economic depression it has never recovered from (own translation) (Kabuya 1995: 55). Ka Mana (2018:313) says that the "return to authenticity was a joke" (own translation) that primarily benefitted Mobutu and his cronies and plunged the Congolese population into unnecessary poverty. This reality seems to be similar to the Zimbabwean.

\subsection{ZANU PF in Zimbabwe}

In Zimbabwe, land reform is a key policy of the current ruling party. The promise of access to land by the majority of citizens made ZANU PF, the liberation movement during colonial time, very popular. The concept of the "lost land" played a central role to motivate the masses to support the war for political liberation (van Niekerk 2015:4). It referred to the land that was lost to the African people through white occupation. Huizer (1991: 13) reiterates the above-mentioned African view on land by saying that the Zimbabwean land worldview is that "land belongs to God, the ancestors and, particularly, to the founders of the lineage, clan or tribe interred therein". The reality of land being owned by a minority was frowned upon. This minority was white. Masenya and Ramantswana (2015:98) stress that "one of the main visible manifestations of white privilege in [Zimbabwe then was] the land possession".

However, according to van Niekerk (2015:4), "there have been numerous reports that [ZANU PF] cadres, and not the poor and landless in whose name the land was taken, benefitted from the land restitution program". The latter is primarily an expropriation from the minority white Zimbabweans to the appropriation of a Zimbabwean minority elite. A direct consequence of this reality has been a decline in "agricultural production, food security, and the economy" (van Niekerk 2015:4). A lesson from this failure is that "land reform must be pragmatic, safeguard commercial agriculture and focus on boosting ordinary subsistence", instead of it being a political scoring game (Gumede 2018:1).

The late president of Zimbabwe, Mugabe, officially recognised the disastrous state of agriculture in 2016. This recognition was a public admission of his government failed land reform policy which had worsened the quality of 
life of the majority of Zimbabweans. For example, UNICEF (the United Nation's children's agency) (2019:3) points out that close to " 3 million Zimbabweans need regular food aid and $40 \%$ of households" experience hunger.

In contrast to the majority of Zimbabweans, Mugabe and his family are known for living "lavishly in a big mansion" (Nkajeni 2019:1). Robert Mugabe's wife is nicknamed "Gucci Grace" for her lavish lifestyle. With his land reform policy and under his rule, in general, Zimbabweans suffered greatly from poverty and many of them had to flee the country and become economic migrants. As the author observes the quality of life of many of his neighbours from Zimbabwe, he has come to believe that Robert Mugabe and his cronies were a "barrier to a better future" for ordinary Zimbabweans (Tony Blair quoted by Singh 2019:2). He pretended to expropriate land to recover the "lost land", yet he and his cronies just changed hands of land ownership monopoly. Under his leadership, the ordinary Zimbabweans did not only remain landless, but they also lost the land benefits they enjoyed under white monopoly such as jobs and access to quality, yet inexpensive agricultural produces. Land access is also a hot topic in the South African political landscape.

\subsection{South African governing party and land access}

Since the African National Congress became the governing party of South Africa in 1994, it prioritised land access for the majority of its population as a way "to redress the injustices of apartheid" (Hall 2004:213). More than two decades after the advent of democracy, land access programs have "fallen far short of both public expectations and official targets" (Hall 2004:213). The land ownership is still displaying the racial inequalities the South African society is known for. The current statistics of the "demographics of land ownership are different", yet they share the common ground that the majority of South Africans (black people) own a negligible percentage of land compared to the white counterparts and the government (Resane 2019:1). This realisation has led some populist politicians to encourage black South Africans to occupy any vacant land they find. It has also led the current South African governing party to adopt a policy of land "expropriation without compensation" as a way to speed up the redistribution process (Ramaphosa 2019:1). The current reality of lack 
of access of land for many ordinary South Africans is a cause of tension in local communities and a "serious dilemma" for the governing party which is struggling to redistribute land in a way that would not lead to an economic collapse similar to Zimbabwe (Holtzhausen 2015:1). However, in many local communities, we see a growing number of land invasion by people living with poverty. In the township of Soshanguve where the author lives, land occupation and invasion now have capitalist and narcissist colours similar to the D.R. Congo and Zimbabwe. The poorest of the poor don't benefit from the land occupation. People are still required to pay a fee to acquire an invaded piece of land. The money usually goes to powerful community leaders who have very little regard for the law. Upon acquiring a piece of land, people are required to valorise it by building a house within two weeks. If the deadline is broken, someone loses land. The latter is sold to someone else who has the financial means to buy land and to build on it within two weeks. Those who can afford are usually the black working class. And someone is allowed to buy as many pieces of the land as they can afford. The author knows many professional neighbours who own many pieces of land in invaded places. They see them as an investment. In the meantime, the poorest of the poor are still landless, because land ownership has become an affordability issue. There seems to be a rise in black professional monopoly in land ownership, which is a shift from the Afrocentric view on land. This reality seems to be blood relative to the Eurocentric view alluded to earlier.

Some African traditional leaders also seem to be closer to the Eurocentric view than Afrocentric, even though they are meant to be the custodian of the emancipation of the black African culture. The current Zulu king is the sole trustee of the Ingonyama Trust, a piece of land that covers an area of $94,361 \mathrm{~km}^{2}$. This land generates an excess of R96 million from rentals which goes to the trustee. Yet, he claims to be the custodian of this land on behalf of the Zulu nation (Mailovich 2019:1).

\subsection{Reflection}

The three examples alluded to above, demonstrate how the land reform programs initiated by some African political leaders did not necessarily lead to the democratisation of access of land. They, instead, were a narcissistic way of changing the skin colour of land access, while keeping 
the same Eurocentric worldview. The South African political analyst Aubrey Mashiqi once pointed out the prevalence of Eurocentrism in the current African socio-political discourse in these terms: "In sub-Saharan Africa, the majority people are a minority culture in terms of dominance. The dominant narrative, logic, power is held by the minority people" (Mashiqi 2019). Until today, the majority of black Africans have too little access to their motherland, and only a few have too much access. In light of this macabre reality, God may be reminding his church to reflect on its privilege and play the role of blessing the landless.

\section{The role of the church}

In places such as the township of Soshanguve, many local churches enjoy spacious pieces of land, while the majority of the residents live on small pieces of land which barely have a playground for children. Therefore, many children play in the streets, community members do not have adequate recreational space or space for meetings. The church could use its acquired land to be a good news agent in society. Good news agency refers to an active seeking of the peace and prosperity of a context in tangible ways so that quality of life can be improved, lives can flourish, and communities can be built from the inside out. This is one of the ways the gospel the church preaches could be seen as "the love of God made visible, able to be touched and felt through physical agents of his kingdom" (Perkins 1993:44). Access to land in a variety of ways is good news for many Africans. The church of sub-Saharan Africa is surrounded by masses of people who are landless and longing to have access to land. The church role in such an important matter would be prophetic because it would be contending for something that is viewed as "the primary source and sustainer of human life" in Africa (Hambira 1999:1). In places like Soshanguve, the church land seems to exclusively be accessible to its members. The latter use it once or twice a week only.

This article suggests that the African church refutes an exclusively Eurocentric understanding of the land and creatively adopt a hybrid model which would use land ownership as an asset to a community where there is land scarcity. It is problematic to observe that, on the one hand, the church has a lot of land space for its agenda which does not affect the majority 
of the population. On the other hand, people of sub-Saharan African communities of poverty, especially in urban areas, are still struggling to find space for recreation, education, communal meetings, even space to bury their loved ones. The lack of land access is not only a political issue. It should also be the concern of the church because it is negatively affecting the quality of life of many God's image-bearers.

Resane (2019:4-5) suggests " 4 roles" the church could play as a good news agent: advocacy, influencing bilateral agreements, journeying with the parties involved towards consensus and facilitating dialogues. These 4 suggestions are important if done well. The church could be involved in advocacy by not only being a role model to making its owned land accessible to local community residents, but also by challenging institutions such as the government to speed up land reform and redistribution processes. It is important to note that some local churches are proactive in their advocacy efforts in making the land they own accessible to ordinary residents of their local communities. This article will allude to three examples:

- Kayole Catholic church in Nairobi, Kenya. This Roman Catholic parish uses its massive piece of land in the middle of a neighbourhood of poverty where people have very little space for housing to serve everyone in that community. He has a centre for refugees, a basketball program opened to the whole community and a medical centre that provides quality healthcare at a very cheap price to the poor.

- The Dutch Reformed churches in Sunnyside and Salvokop in the city centre of Pretoria, South Africa. These congregations have opened their doors to serve their neighbours in taking the youth and children out of the busy streets of Pretoria city centre. They run several educational programs geared towards the youth.

- The Baptist church in Rwanda uses its facilities and land in various locations to gather community members in cooperatives where they cultivate the land together and sell their harvest for a profit. In these cooperatives, membership is not exclusive to church members.

COVID-19 has also been an opportunity for the church to make its land accessible. Such was the case in the city of Pretoria where "a charismatic church opened its facility for 91 homeless men using substances ... 3 
inner-city churches opened their spaces, and a suburban church in a gated community opened up for 20 older homeless men" (De Beer 2020:3).

These examples give hope for what the church could do as a solution-seeking actor in matters of land access for ordinary Africans. Slum communities, townships and many other forms of urban poor communities need land space for the improvement of the quality of life of their residents. Many local churches have the physical assets that could help answer such needs of access to land. A meaningful step to make would be to act and remain involved in the conversation as a proactive role player.

\section{Conclusion}

This article used a biblical interpretive framework of Jeremiah 29:7 to reflect on the role of the church in the current conversation of access to land in sub-Saharan Africa. The church is a privileged institution with many assets, including land ownership. Its privilege was acquired from its partnership with the colonisers and existing African governments. This article stressed that the church should take a step to self-introspect and look at its owned land as an asset for it to be a tangible good news agent to the landless. The church is physically present in local communities and is still enjoying the privilege of land ownership. This article stressed that the church should use its land assets to serve a whole neighbourhood or community. Currently, people that have access to the church land are mostly its members only. This exclusive use of land makes the church to be an accomplice alongside governments and the African elite in impeding the democratisation of land access. The article alluded to examples of churches that are leading by example and could be an inspiration to others to make their land accessible.

\section{References}

Amanze, J.N. 2002. African traditional religions and culture in Botswana: A comprehensive textbook. Gaborone: Pula Press.

Brueggemann, W. 2001. The people prophetic imagination, $2^{\text {nd }}$ ed. Minneapolis, MN: Fortress Press. 
Bolnick, J and van Rensburg, G. 2005. The Methodist Church's initiative to use its vacant land to support homeless people's housing and livelihoods in South Africa. In Environment \& Urbanization 17(1) April 2005.

Catholic Church, 2012. Vision for land reform in South Africa. Southern African Catholic bishops' conference: Justice and Peace. Pretoria.

De Beer, S.F. 2020a. Homelessness and Covid-19 in the City of Tshwane: Doing liberation theology undercover - A conversation with Ivan Petrella. HTS Teologiese Studies/ Theological Studies 76(1), a6209. https://doi.org/ 10.4102/hts.v76i1.6209

De Beer, S.F. 2020b. Urban Africa 2050: Imagining theological education/ formation for flourishing African cities. Unpublished article.

Gumede, W. 2018. Lessons from Zimbabwe's failed land reform. [Online]. Available: News24https://www.news24.com: Cape Town. [Accessed: 14/09/2019].

Hall, R. 2004. A political economy of land reform in South Africa. Review of African Political Economy 31(100):213-227.

Hambira, R. 1999. Those who do not know the village they come from ... In Kobia, S. (Ed.). Land and the post-colonial crisis in Africa. Echoes. Geneva: World Council of churches publication.

Holtzhausen, H. 2015. Ubuntu and the quest for land reform in South Africa. Verbum et Ecclesia 36(2), 1-8.

Huizer, G. 1991. Folk spirituality and liberation in Southern Africa. Centre d'etude d'Afrique Noire. Bordeaux, France: Domaine Universitaire.

Lephoto, M.B. 2020. The restitution of Roman Catholic Church land to indigenous people in post-apartheid South Africa: 1994-2014. HTS Teologiese Studies/ Theological Studies 76(1):a5607.

Kabuya, L.S. 1995. La conquite des libertes en Afrique. Essai de sociologie politique. Kinshasa: Editions Noraf.

Ka Mana 2018. Philosophie africaine et culture. Comprendre la culture africaine et ses enjeux de civilisation. Beau Bassin, Mauritius: Editions univeritaires europeennes. 
Katongole, E. 2017. Born from lament. The theology and politics of hope in Africa. William B. Eerdmans publishing company: Grand Rapids.

Linthicum, R.C. 2003. Transforming power: Biblical Strategies for Making a Difference in Your Community. Downers Grove: Intervarsity press.

Maathai, W. 2009. The challenge for Africa. A new vision. London: William Heinemann.

Mailovich, C. 2019. Land panel recommends Ingonyama Trust Act be scrapped or reviewed. [Online]. Available: www. Businesslive.co.za. Johannesburg. [Accessed: 24/09/2019].

Masenya, M. and Ramantswana, H. 2015. Lupfumo lu mavuni (Wealth is the land): In search of the Promised Land (cf. Ex. 3-4) in the postcolonial, post-apartheid South Africa. In West, G. \& Tshehla, M. S. (eds.). Journal of Theology for Southern Africa 15(1):96-116.

Mashiqi, A. 2019. Comment made on radio Power FM on 27/10/2019. Theme of discussion: Reflection on the resignation of the D.A. (the South African main opposition).

Meredith, M. 2011. The fate of Africa: A history of the continent since independence. London: Hachette.

Muzenda, D. 2020. "Land as a womb": Impact of gender imbalances on land redistribution in the Third Chimurenga. Verbum et Ecclesia 41(1), a2049. https://doi.org/10.4102/ ve.v41i1.2049

Nkajeni, U. 2019. What do Zuma and Mugabe have in common. Well, big lavish homes for one. [Online]. Available: www.timeslive.co.za. [Accessed: 13/09/2019].

Nkosi, Z. 1999 Spirituality, land and land reform in South Africa. In Kobia, S. (Ed.). Land and the post-colonial crisis in Africa. Echoes. Geneva: World Council of churches publication.

Niemandt, C.J.P. 2019, Rooted in Christ, grounded in neighbourhoods A theology of place. Verbum et Ecclesia 40(1):a1997. https://doi.org/ 10.4102/ve.v40i1.1997. 
Ofo'ia, N. 2017. Revisiting the Babylonian Exile in Jeremiah 29: 1-14:

A Samoan La-tō Reading using an Oceanic Hermeneutic. Doctoral dissertation. University of Otago, Dunedin.

Perkins, J.M. 1993. Beyond Charity. The call to Christian community development. Grand Rapids: Baker Books.

Ramaphosa, M.C. 2019. Land redistribution without compensation on government agenda. [Online]. Available: www.timeslive.co.za. [Accessed: 27/08/2019].

Resane, K.T. 2019. The role of the church in the land debate. Scriptura 118 (2019:1):1-9. Stellenbosch.

Singh, K. 2019. Thabo Mbeki hails Robert Mugabe as a true African patriot. News24.com. [Online]. [Accessed: 15/09/2019].

Tafira, K. 2015. Why land evokes such deep emotions. [Online]. Available: www.theconversion.com [Accessed: 29/08/2019].

Terreblanche, S. 2014. Western empires, Christianity, and the inequalities between the West and the Rest. Johannesburg: Penguin Books.

UNICEF, 2019. The State of the World's Children 2019. Children, food, and nutrition: Growing well in a changing world. [Online]. Available: https://www.unicef.org/zimbabwe/reports/state-worlds-children-2019 [Accessed: 26/10/2019].

Van Niekerk, A.S. 2015. The lost land and the earth mother: African mythology and the issue of land in Southern Africa. Unpublished lecture. Pretoria: University of Pretoria.

Vorster, N. 2019. Land and identity in South Africa: An immanent moral critique of dominant discourses in the debate on expropriation without compensation. HTS Teologiese Studies/ Theological Studies 75(4):a5290. https://doi.org/ 10.4102/hts.v75i4.5290

Weiner, D. and Harris, T. 2003. Community-integrated GIS for land reform in South Africa. URISA Journal 15(2):61-73. 